UDC 336.713

JEL Classification: D4, G01, G21, G28

http://doi.org/10.21272/mmi.2019.1-25

Tatjana Vasiljeva,

D.Sc., Professor, University of Business, Arts and Technology, Latvia

Anton Stadnyk,

First Ukrainian International Bank «PUMB»; Sumy State University, Ukraine

\title{
INNOVATIVE APPROACHES TO EVALUATION OF CONCENTRATION OF THE BANKING SYSTEM AS A BASIS OF IMPROVING THE STATE CRISIS MANAGEMENT
}

Abstract. Of the totality of endogenous factors influencing the occurrence of banking crises, the least studied and most ambiguous, in our opinion, is the effect of concentration. Because of a theoretical study, it has been identified that an increase in market concentration can act as a signal of future market degradation and a possible crisis in it. We believe that in modern conditions of development of both the world economy and the economy of Ukraine, the assessment of the concentration level should be one of the key elements of the crisis management system of the banking system since it has a significant impact on its level. In view of this, the authors proposed innovative approaches to evaluating the level of concentration in the banking system, consisting of an integrated and multi-stage analysis of the banking market using: special statistical tests (parametric ANOVA test and nonparametric KruskalWallis test), a set of special indicators for assessing market concentration (the Concentration Ratio CR4; the Herfindahl-Hirschman Index; the Rosenbluth Index; the Comprehensive Industrial Concentration Index; the Entropy Measure; the Gini Coefficient) and regression analysis with dummy variables. Empirical analysis focuses on data on the banking system of Ukraine for the period from 2004 to 2017. The research confirms that in the banking system of Ukraine there is an increase in concentration. The result is a degradation of the banking system since the monopolization of the market leads to a distortion of the functioning of market mechanisms. The obtained results suggest that in order to overcome the first threats of a crisis, the National Bank of Ukraine, as the main regulator of the banking system, should develop and apply measures aimed at decreasing the concentration of assets and, later, when the situation stabilizes, create favourable conditions for banks to increase their portfolios. Thus, the research results are innovative and extremely important in the context of organizing preventive state crisis management, the main goal of which is not to combat the effects of the banking crisis but to eliminate its main causes even before its occurrence.

Keywords: bank competition, bank concentration, banking crises, management.

Introduction. The nature of the banking crisis in Ukraine and the reasons for its occurrence, the nature of deployment and the consequences are consistent with the general concept of the causes of crises. They are based on complex interactions of destructive external (including global) and internal factors.

In crisis management, it is extremely important to correctly identify and assess the causes and factors that generate the crisis, affecting the nature of its occurrence and the magnitude of the consequences. These data should be included in the system of anti-crisis regulatory actions at the micro and macro levels of the banking system. Of the totality of endogenous factors influencing the occurrence of banking crises, the least studied and most ambiguous, in our opinion, is the effect of concentration.

Given the current trends in the banking system of Ukraine, it is necessary to analyze the dynamics of its concentration level. This is necessary to identify potentially hazardous processes in the banking system of Ukraine, in particular its degradation, which may later trigger a banking systemic crisis.

After all, the level of competition in the market directly influences the main processes occurring on it, and its basic characteristics such as prices, quality of services, development dynamics, efficiency, and the like.

Based on this, the goal of the article is to develop an approach to assessing the concentration of the banking system as the basis for improving the state crisis management.

Cite as: Vasiljeva, T., \& Stadnyk, A. (2019). Innovative Approaches to Evaluation of Concentration of the Banking System as a Basis of Improving the State Crisis Management. Marketing and Management of Innovations, 1, 302-313. http://doi.org/10.21272/mmi.2019.1-25 
T. Vasiljeva, A. Stadnyk. Innovative Approaches to Evaluation of Concentration of the Banking System as a Basis of Improving the State Crisis Management

Literature Review. The generalization of existing approaches to justifying the influence of concentration on the stability of the banking system suggests the existence of several concepts describing their interaction.

Proponents of the concept of "concentration - stability» believe that non-concentrated banking systems are more vulnerable to crises than concentrated ones (examples are the banking systems of China and Canada). This is explained by the fact that banking systems with a high level of concentration are more resistant to external risks, easier to control by the state and more profitable.

Beck et al. (2006) using data on 69 countries from 1980 to 1997 find that crises are less likely in economies with more concentrated banking systems even after controlling for differences in commercial bank regulatory policies, national institutions affecting competition, macroeconomic conditions, and shocks to the economy.

Using data on 76 countries from 1990 to 2007, Doll (2010) revealed evidence that concentrated banking systems are less likely to experience episodes of systemic banking crises. Besides that, the results research also supported the competition-fragility hypothesis. Especially banking sectors that are (almost) perfectly competitive are prone to financial crises. Although competition negatively affects financial stability, policymakers should not curtail competition. Instead, they should adopt an incentive compatible financial safety net and monitor banks more closely.

The research results of Deltuvaite (2010) confirm the existence of the concentration-stability relationship in banking system. The results of analysis indicate that banking crises are less frequent, and the fiscal costs incurred in the resolution of banking crises and the broader welfare losses to the economy are less in countries with more concentrated banking systems.

Diallo (2015) studied the relationship between bank competition and stability for 145 countries over the period 1997-2010, using the Boone indicator, the Lerner and the adjusted Lerner indices, and two econometric methods. Him results show that bank competition is detrimental to bank stability, and it also shortens the survival time of banking systems.

According to the second concept of «concentration - fragility», concentrated banking systems are less stable than non-concentrated ones. This is because, firstly, large banks can receive subsidies from the state (since they are «big enough to fail») and at the expense of such financial assistance to carry out operations with a high level of risk, thereby reducing the stability of the banking system. Secondly, oligopoly or monopoly in the banking market leads to higher interest rates and encourages lending to more risky projects (an example of South-East Asia).

Amidu and Wolfe investigated, how the level of competition affects diversification and stability of the banking sector using a sample of 978 banks in 55 emerging and developing countries over 2000-2007. Their core finding is that competition increases stability as diversification across and within both interest and non-interest income generating activities of banks increases. The greater competition in the banking sector enhances stability (Amidu and Wolfe, 2013).

The results of research of Djalilov at al. (2015) have revealed that higher competition favours less risking taking behaviour in the banking sector, consistent.

S. Kasman and A. Kasman (2015) analysed the impact of competition and concentration on bank stability in the Turkish banking industry over the period 2002-2012. The main results indicate that competition is negatively related to the non-performing loans ratio but positively related to the Z-score are used as proxies for bank stability. The results further indicate that greater concentration has a positive impact on the NPL and a negative impact on the Z-score.

Shijaku (2017) revealed that concentration is negatively related to bank stability in the case in Albania. It reveals that bank concentration tends to enhance the likelihood that a country will suffer systemic bank fragility. 
T. Vasiljeva, A. Stadnyk. Innovative Approaches to Evaluation of Concentration of the Banking System as a Basis of Improving the State Crisis Management

Several studies have revealed the presence of contradictory and unambiguous interactions between these indicators.

Davis (2007) draws attention to that the relationships between banking concentration on the one hand, and financial stability, on the other, are complex and depend upon multi-faceted aspects of regulatory policy and institutional arrangements.

Boyd at al. (2009) find that banks' probability of failure is negatively and significantly related to measures of competition.

Schaeck at al. (2009) have revealed that greater competition is associated with lower risk of crisis; higher concentration per se does not increase the risk of crisis; a more restrictive regulatory system may contribute to the build-up of instability. In further studies, scientists have found that that competition is stability-enhancing, and that the stability-enhancing effect of competition is greater for healthy banks than for fragile ones. Their results suggest that efficiency is the conduit through which competition contributes to stability and that regulators must condition policy on the health of existing banks (Schaeck and Cihak, 2013).

Studies Titko at al. (2015) have not confirmed the existence of any interconnections between the level of concentration and the financial stability of the banking system.

Barra and Zotti (2017) explores the relationship between bank market concentration and financial stability of financial institutions in Italy between 2001 and 2012. The authors conclude that boosting market power increases bank failure in very concentrated markets while leads to higher financial stability in already competitive markets.

Ben Ali at al. (2018) analyzed the relationship between banking concentration and financial stability for a sample of 156 developed and developing countries during the period 1980-2011. Their results provide evidence that concentration does not directly affect the stability of the financial system. The researchers found that the concentration has an indirect positive and stabilizing impact on financial stability through the profitability channel and a negative and destabilizing impact through the interest rate channel. Their results support the existence of a stabilizing effect of concentration on financial stability and the absence of a destabilizing interest channel for developing countries. They also indicate that concentration has a direct and indirect effect on financial stability during crisis periods, but no direct effect on financial stability during normal periods.

Important findings obtained Calice and Leonida (2018). They revealed that at lower levels of concentration, increasing concentration improves banking system stability via profitability. At higher levels of concentration, increasing concentration makes the banking system more fragile because of the cost of credit, diversification and the ease of monitoring. For intermediate levels, concentration has no significant effect on financial stability, as the competing moderators cancel each other out. The results suggest that an intermediate level of concentration may be optimal for welfare.

Methodology and research methods. Since the purpose of the study is to search for interactions between the concentration of the banking system and the crisis processes in it, it is necessary to quantify the level of concentration.

In this paper for analyze concentration were proposed to use the multi-stage analysis using special statistical tests (parametric and non-parametric), a set of special indicators for assessing market concentration and regression analysis with dummy variables.

After the relevant data set has been formed, it is checked for uniformity. To this end, the hypothesis about the data belonging to a single general population is tested.

To prove that groups of data belong to the same or different general sets, parametric and nonparametric tests are used in statistics. This study proposes the use of the ANOVA parametric test (Moore at al., 2014) and the Kruskal-Wallis non-parametric test (Corder and Foreman, 2011). 
T. Vasiljeva, A. Stadnyk. Innovative Approaches to Evaluation of Concentration of the Banking System as a Basis of Improving the State Crisis Management

Additionally, to test the market for uniformity, we suggest using a multivariate regression analysis based on dummy variables. The purpose of the meeting is to determine the ability of individual banks to influence the market. The availability of such a possibility bites the evidence of the non-competitive market (Heggestad and Rhoades, 1978).

During the analysis of the regression model, first, one should pay attention to the statistical significance of the coefficients with dummy variables. If $p<0.05$, then the conclusion is made about the ability of this variable to affect the population.

The regression model with dummy variables is as follows:

$$
Y_{t}=b_{0}+b_{1} D_{1 t}+b_{2} D_{2 t}+\cdots+b_{n} D n_{t}+\varepsilon_{t}
$$

where $Y_{t}$ - value of $\mathrm{Y}$ in period $\mathrm{t} ; b_{0}$ - mean over the data set (total assets of the Ukrainian banking system); $b_{n}$ - mean by data group (the impact of an individual bank on the banking system); $D_{n t}$ - dummy variable can thus be thought of as a truth value represented as a numerical value 0 or 1 ; has a value of 0 will cause that variable's coefficient to have no role in influencing the dependent variable (for example, we have the data of JSC «Oschadbank» that do not correspond to the data of PJSC CB «PrivatBank»), while when the dummy takes on a value 1 its coefficient acts to alter the intercept (such as of PJSC CB «PrivatBank»); $\varepsilon_{\mathrm{t}}$ - random error for period $\mathrm{t}$.

To clear evidence of the nature of the market from the standpoint of its concentration, it is necessary to use special indicators to measure.

Scientists are actively studying the indicators concentration applied in the sphere of banking, and are discussed their main properties, advantages and disadvantages (Bikker and Haaf, 2002; Cetorelli, 2004; Alegria and Schaeck, 2006; Claessens, 2009; Florian, 2014; Bekmurodova Adhamovna, 2014; Bikker and Spierdijk, 2017).

The most common concentration indicators include the K-Bank Concentration Ratio, the HerfindahlHirschman index $(\mathrm{HHI})$, the Hall-Tideman index, the Rosenbluth index, the Comprehensive Industrial Concentration Index (CCl), the Hannah-Kay index, the U-index, the Hause indices, the Entropy measure, and Gini Coefficient.

The choice of an indicator influences conclusions regarding the implications of concentration, and the usefulness of the different approaches hinges on data availability, the conceptions of competition assumed, and the questions being addressed.

One of the most frequently used measures of concentration in the empirical literature is the concentration ratio. The K-Bank concentration ratio $(C R k)$ measures the market share of the top $\mathrm{k}$ bank in the banking system:

$$
C R k=\sum_{i=1}^{K} s_{i} \text { with } s_{i} \geq \cdots \geq s_{k} \geq s_{n}, \forall N \geq K
$$

where si - the market share of the i'th bank, when banks are ranked in descending order of market share and $\mathrm{N}$ is the total number of the banks (Florian, 2014).

Based on the results of Naldi and Flamini (2014), in the research will be used CR4 index (the concentration ratio for the top 4 banks). Levels of competition and the CR4:

$\approx 100 \%$ - Monopoly;

$>60 \%$ - Tight Oligopoly or Dominant Firm with a Competitive Fringe;

$40 \%-60 \%$ - Loose Oligopoly or Monopolistic Competition;

$<40 \%$ - Effective Competition or Monopolistic Competition. 
T. Vasiljeva, A. Stadnyk. Innovative Approaches to Evaluation of Concentration of the Banking System as a Basis of Improving the State Crisis Management

$\approx 0$ - Perfect Competition (Naldi and Flamini, 2014).

Practical advantages of discrete measures are simplicity and limitation of required data (Repkova and Stavarek, 2014).

Cumulative measures of concentration, on the other hand, explain the entire size distribution of banks, implying that structural changes in all parts of the distribution influence the value of the concentration index. Cumulative measures of the concentration include e.g. the Herfindahl-Hirschman Index (HHI), the Comprehensive Industrial Concentration Index, the Rosenbluth Index and the Entropy Measure (Repkova and Stavarek, 2014).

The Herfindahl-Hirschman Index $(\mathrm{HHI})$ is the concentration measure most frequently used by researchers. The $\mathrm{HHI}$ is more data intensive than the number of firms or the CRk, insofar as it requires information on the market share of each firm. It is computed by summing the squares of the market share of all bank:

$$
H H I=\sum_{i=1}^{n}\left(\frac{R_{i}}{R}\right)^{2}
$$

where $n$ - total number of banks in the market; $R_{i}$ - the market share of the i-th banks; $R$ - all the market shares.

The banking industry is regarded to be a competitive if the $\mathrm{HHI}$ is less than 0.10 , a somewhat concentrated if the $\mathrm{HHI}$ lies between 0.10 and 0.18 , and a very concentrated if the $\mathrm{HHI}$ is more than 0.18 (Rhoades, 1995).

The Rosenbluth index $\left(I_{R}\right)$ is an index of absolute concentration in markets:

$$
I_{R}=\frac{1}{2 \times \sum_{i=1}^{n}\left(i \times R_{i}\right)-1} ;[1 / \mathrm{n} ; 1]
$$

Thus, the smaller a bank, the larger it's ranking which increases its contribution to the index. The Rosenbluth Index, therefore, attaches more significance to the small bank than the HHI. The higher the index value, the more monopolized the market (Mynhardt at al., 2017).

The Comprehensive Concentration Index $(\mathrm{CCl})$ is calculated by taking the market share of the largest firm in the industry and adding a summary index covering the remaining firms in an industry:

$$
C C I=R_{1}+\sum_{i=2}^{n} R_{i}^{2} \times\left(1+\left(1-R_{i}\right)\right) ;[0 ; 1]
$$

The higher the index value, the more monopolized the market (Mynhardt at al., 2017).

The use of the Entropy measure $(E)$ allows, by reducing the importance of market shares of significant market participants, to strengthen the importance of small:

$$
E=\frac{1}{n} \sum_{i=1}^{n} R_{i} \times \ln \frac{1}{R_{i}}
$$

Small values of the Entropy Index reflect high concentration (Mynhardt at al., 2017).

In addition, we consider it expedient to use the Lorenz curve, which allows visualizing the level of inequality in the market. It consists of two lines: the first reflects the ideal distribution of the shares of participants in the market, and the second shows the real distribution of the shares of participants in the market. The distance of the actual Lorenz curve and the diagonal (or line of equality) indicates the uneven distribution of shares in the market and its non-competitive nature. 
T. Vasiljeva, A. Stadnyk. Innovative Approaches to Evaluation of Concentration of the Banking System as a Basis of Improving the State Crisis Management

The quantitative interpretation of the Lorentz curve is the Gini coefficient $(G)$ :

$$
G=\frac{\sum_{i=1}^{n} \sum_{j=1}^{n}\left|R_{i}-R_{j}\right|}{2 n^{2} \bar{R}}
$$

$\bar{R}$ - the arithmetical mean of the share banks in the market.

The Gini coefficient is a relative measure of concentration that measures the inequality between banks in the relevant market. Indicator is in range between zero and one. If the banks in a market have nearequal market share, the Gini coefficient is near zero. If most of the banks have very low market share but there exist, one or a few banks providing most of the market share then the Gini coefficient is near one.

The higher the Ginny coefficient, the higher the uneven distribution of market shares between market participants and, consequently, the higher the concentration in the market (Plastun at al., 2018).

Results. The first stage of studying the concentration in the Ukrainian banking industry involves the selection of a baseline for evaluation. Based on the building of a correlation matrix of interconnections between the main indicators of the activities of Ukrainian banks, it was found that the choice of the indicator does not affect the results of the analysis (Table 1). Based on this, the indicator uses total assets.

Table 1. Correlation matrix of the key indicators of activity of the Ukrainian banks

\begin{tabular}{|c|c|c|c|c|c|c|}
\hline Indicator & Assets & Bank funds & Loan & Liability & Deposits & Capital \\
\hline Assets & 1 & 0.91 & 0.97 & 1.00 & 0.99 & 0.69 \\
\hline Bank funds & 0.91 & 1 & 0.92 & 0.89 & 0.93 & 0.81 \\
\hline Loan & 0.97 & 0.92 & 1 & 0.96 & 0.97 & 0.74 \\
\hline Liability & 1.00 & 0.89 & 0.96 & 1 & 0.98 & 0.63 \\
\hline Deposits & 0.99 & 0.93 & 0.97 & 0.98 & 1 & 0.73 \\
\hline Capital & 0.69 & 0.81 & 0.74 & 0.63 & 0.73 & 1 \\
\hline
\end{tabular}

Sources: own processing

The study must base on a statistically relevant data sample. The problem is that the number of the Ukrainian banks is not stable and has constantly changed during the period of analysis (Fig. 1).

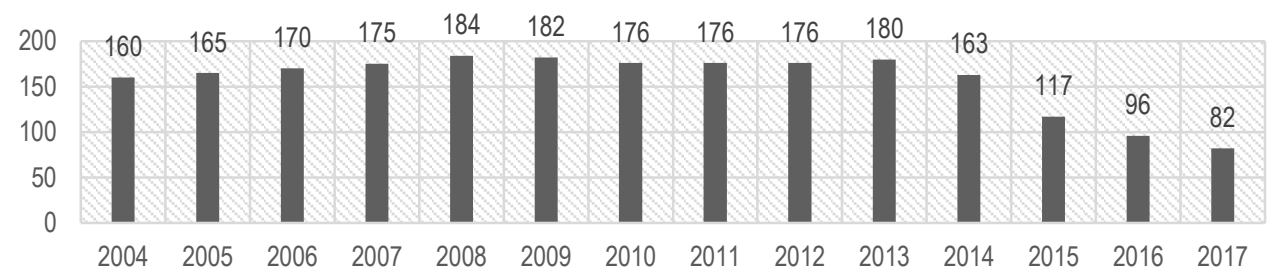

Figure 1. Number of the Ukrainian banks over the period 2004-2017

Sources: created by the authors based on data compiled by the National Bank of Ukraine

Therefore, it is impossible to form a certain constant number of banks for a sample without preliminary data processing. In addition, a significant number of banks are characterized by a low share in the assets of the banking system of Ukraine. This leads to the need to separate into selected groups.

In this study, we propose to use the threshold values of the bank's share in the total assets of the bank system as a criterion for its inclusion in the main group or in the group «other banks». 
T. Vasiljeva, A. Stadnyk. Innovative Approaches to Evaluation of Concentration of the Banking System as a Basis of Improving the State Crisis Management

Based on the analysis of the asset of the Ukrainian banking system at the beginning of 2018, it was proposed to use as a threshold for the inclusion of a bank in a certain group share in total banking assets of $1 \%$. Thus, it will be possible to form a representative sample and not lose the adequacy of the sample.

As a result, a list of 25 banks and a group «other banks» was a format, containing the remaining banks whose assets are less than $1 \%$. Analysis of the behavior of this sample in dynamics showed its key flaw: if in 2017, the group "other banks» was only $6 \%$ and generally corresponded to a role in the banking system of Ukraine in terms of its concentration, then in other periods the share of group "other banks» reached $38 \%$. This distorts estimates of market concentration. Thus, the use of this approach deforms the data sample.

Since the purpose of the study is to assess the concentration of the Ukrainian banking system, it is necessary not to analyze the total assets for the group "other banks», but to single out a typical representative of this group. It must have the basic quantitative characteristics of the bank identified as «other banks». To do this, we propose to carry out averaging of the bank assets of the group «other banks» using formula (9):

$$
A_{\text {other }}=\frac{\sum_{i=1}^{n} A_{i}-\sum_{i=1}^{k} \text { A }_{\text {other }}}{N-N_{\text {other }}}
$$

where $A_{\text {other }}$ - mean size of a bank asset in the group «other banks»; $A_{i}$ - assets of the i-th bank; Aother $_{i}$ - assets of the i-th bank in the group «other banks»; $N$ - total number of banks; $N_{\text {other }}$ - total number of banks in the group «other banks».

Of this approach, the group «other banks» is of $0.28 \%$ of the assets of the banking system. In our opinion, this corresponds to the real role of the banks of this group in the banking system of Ukraine.

Visualization of the structural analysis of assets of the Ukrainian banking system is presented in Figure 2.

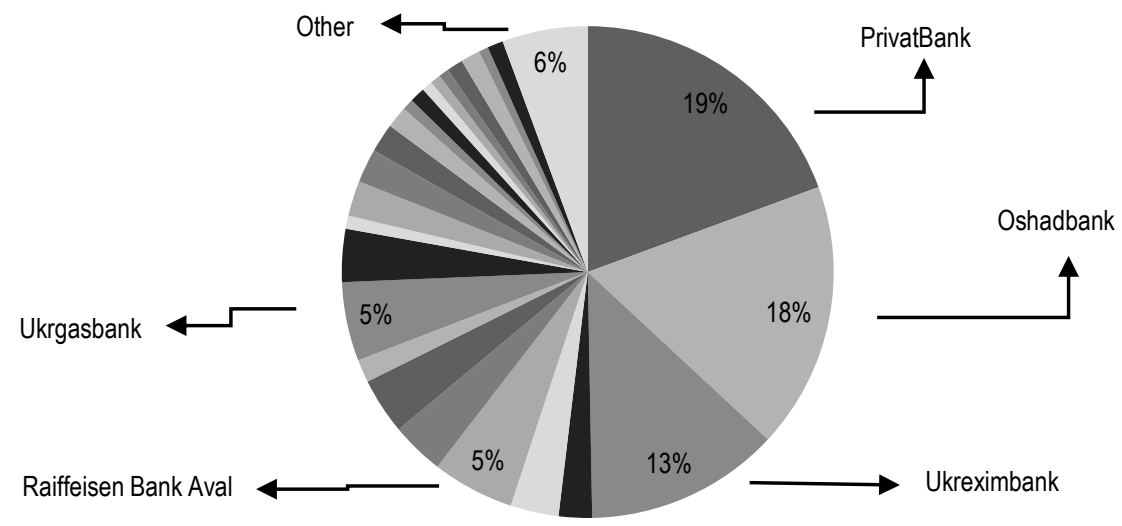

Figure 2. The structure of assets of the Ukrainian banking system according to the results of 2017

Sources: own processing based on data compiled by the National Bank of Ukraine

To prove that groups of data belong to the same or different general sets, used of the ANOVA parametric test and the Kruskal-Wallis non-parametric test. 
T. Vasiljeva, A. Stadnyk. Innovative Approaches to Evaluation of Concentration of the Banking System as a Basis of Improving the State Crisis Management

Table 2. Results of statistical tests for the indicator «assets of banks» for the period 2004-2017

\begin{tabular}{|l|c|}
\hline \multicolumn{1}{|c|}{ Indicator } & Value \\
\hline \multicolumn{1}{|c|}{ Results of ANOVA parametric test } \\
\hline The actual value of F-criterion & 18.33 \\
\hline The critical value of F-criterion & 1.54 \\
\hline df & 25 \\
\hline P Value & 0.00 \\
\hline Null hypothesis & rejected \\
\hline \multicolumn{2}{|c|}{ Results of Kruskal-Wallis non-parametric test } \\
\hline Adjusted H & 204.85 \\
\hline Degrees of freedom & 24 \\
\hline P value & 0.00 \\
\hline The critical value & 36.41 \\
\hline Null hypothesis & rejected \\
\hline
\end{tabular}

Sources: own processing

According to the results of statistical tests, the data do not apply to the general population.

For additional confirmation, multivariate regression analysis was performed using dummy variables (Table 3).

Table 3. Multivariate regression analysis results using dummy variables *

\begin{tabular}{|c|c|c|c|}
\hline & Coefficients & t Statistic & P-value \\
\hline Average & 0 & 3.48466 & 0.000555 \\
\hline
\end{tabular}

${ }^{*}$ The parameters of the regression equation: $R=0.80 ; R 2=0.64$; Normalized $R 2=0.62 ; F(26,351)$ $=24.67 ; p<0.0000$

Sources: own processing

A significant number of variables has a statistically significant effect on the resulting indicator $(p<0.00)$, which should not be the case in a highly competitive market. This confirms the non-competitive nature of the banking system of Ukraine.

Since the results of a preliminary statistical analysis indicate the non-competitive nature of the Ukrainian banking system, we will conduct an in-depth concentration study using the special indicators of concentration for this (table 4).

Table 4. Dynamics of the indicators of the concentration (in asset terms) of the Ukrainian banking system for the period 2004-2017

\begin{tabular}{|c|c|c|c|c|c|c|}
\hline Period & CR4 & HHI & IR & CCI & E & G \\
\hline 2004 & $53.27 \%$ & 0.09 & 0.10 & 0.19 & $10.31 \%$ & 0.47 \\
\hline 2005 & $49.10 \%$ & 0.09 & 0.09 & 0.18 & $10.50 \%$ & 0.46 \\
\hline 2006 & $45.30 \%$ & 0.08 & 0.09 & 0.18 & $10.60 \%$ & 0.44 \\
\hline 2007 & $45.88 \%$ & 0.08 & 0.09 & 0.17 & $10.78 \%$ & 0.40 \\
\hline 2008 & $43.63 \%$ & 0.08 & 0.09 & 0.17 & $10.75 \%$ & 0.42 \\
\hline 2009 & $44.29 \%$ & 0.08 & 0.09 & 0.17 & $10.79 \%$ & 0.42 \\
\hline 2010 & $48.04 \%$ & 0.09 & 0.09 & 0.18 & $10.60 \%$ & 0.43 \\
\hline 2011 & $49.47 \%$ & 0.09 & 0.09 & 0.19 & $10.55 \%$ & 0.41 \\
\hline
\end{tabular}


T. Vasiljeva, A. Stadnyk. Innovative Approaches to Evaluation of Concentration of the Banking System as a Basis of Improving the State Crisis Management

\begin{tabular}{|l|l|l|l|l|l|c|}
\hline \multicolumn{1}{|c|}{ Continue Table 4 } \\
\hline 2012 & $40.73 \%$ & 0.10 & 0.09 & 0.21 & $10.42 \%$ & 0.41 \\
\hline 2013 & $54.77 \%$ & 0.11 & 0.10 & 0.23 & $10.20 \%$ & 0.42 \\
\hline 2014 & $53.09 \%$ & 0.10 & 0.09 & 0.20 & $10.43 \%$ & 0.41 \\
\hline 2015 & $55.18 \%$ & 0.11 & 0.10 & 0.23 & $10.23 \%$ & 0.41 \\
\hline 2016 & $55.22 \%$ & 0.10 & 0.10 & 0.23 & $10.31 \%$ & 0.41 \\
\hline 2017 & $58.33 \%$ & 0.11 & 0.10 & 0.25 & $10.10 \%$ & 0.45 \\
\hline
\end{tabular}

Sources: own processing

The shape of the Lorenz curve points to a certain intensification of inequality among Ukrainian banks (Figure 3). The higher a degree of its curvature is, the greater the inequality in the distribution of assets among banks, expressed by the Gini coefficient, becomes.

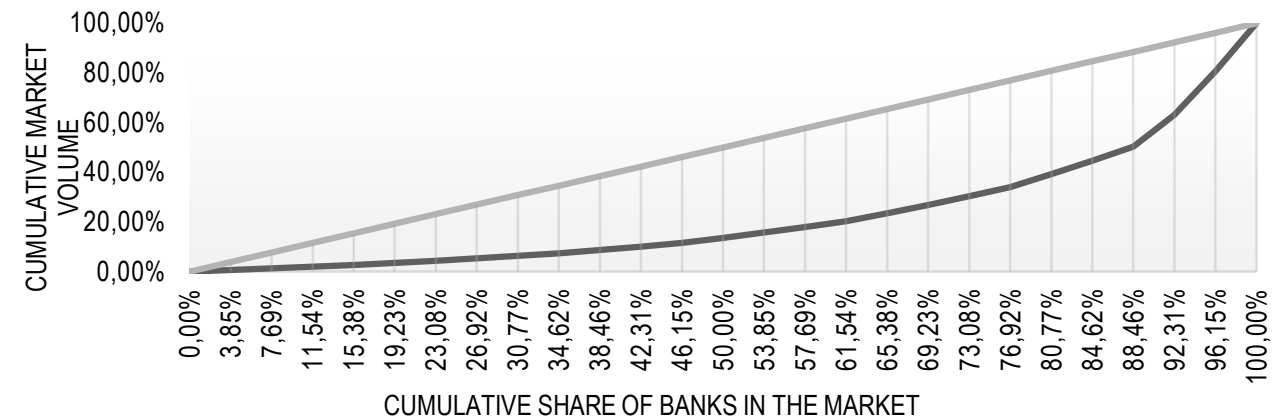

Figure 3. Lorenz curves for assets of the Ukrainian banking system in 2017

Sources: own processing

A summary of the results of the calculation of the indicators of the concentration (in asset terms) is presented in Table 5.

Table 5. Trends of the concentration (in asset terms) of the Ukrainian banking system

\begin{tabular}{|c|c|c|c|}
\hline Indicators & 2012 year & 2017 year & Tendency \\
\hline $\begin{array}{c}\text { The Bank Concentration } \\
\text { Ratio CR4 }\end{array}$ & $\begin{array}{c}\text { Effective competition / } \\
\text { Market-dominant banks }\end{array}$ & $\begin{array}{c}\text { Market-dominant } \\
\text { banks / Oligopoly }\end{array}$ & $\begin{array}{c}\text { Lowering the level of } \\
\text { competition }\end{array}$ \\
\hline $\begin{array}{c}\text { The Herfindahl-Hirschman } \\
\text { Index }(\mathrm{HHI})\end{array}$ & Low concentration & $\begin{array}{c}\text { Medium } \\
\text { concentration }\end{array}$ & $\begin{array}{c}\text { Lowering the level of } \\
\text { competition }\end{array}$ \\
\hline $\begin{array}{c}\text { The Rosenbluth Index } \\
\text { Industrial Concentration } \\
\text { Index (CCl) }\end{array}$ & Low concentration & $\begin{array}{c}\text { Medium } \\
\text { concentration }\end{array}$ & $\begin{array}{c}\text { Lowering the level of } \\
\text { competition }\end{array}$ \\
\hline The Entropy Measure & High probability of the & $\begin{array}{c}\text { Hedium } \\
\text { concentration }\end{array}$ & $\begin{array}{c}\text { Lowering the level of } \\
\text { competition }\end{array}$ \\
\hline the & High concentration & High concentration & $\begin{array}{c}\text { Lowering the level of } \\
\text { competition }\end{array}$ \\
\hline
\end{tabular}

Sources: own processing 
T. Vasiljeva, A. Stadnyk. Innovative Approaches to Evaluation of Concentration of the Banking System as a Basis of Improving the State Crisis Management

The data in Table 5 indicate negative trends in the banking system of Ukraine. The reform of the banking system, on the one hand, led to its purification, and, on the other, to a decrease in the level of competition in the market. The result of this is that a limited number of market participants, mostly stateowned, controls the banking system

Overcoming the «negative effects» of markets, including the processes of their monopolization, is the prerogative of the subjects of banking regulation and supervision. The system of such activities should include:

- coordination of actions of all stakeholders to promote the increase of the competitive environment in the market and counteract the manipulation of individual participants;

- provision of market users with access to information about market participants for their informed decisions:

- ensuring market transparency to eliminate information asymmetries and prevent negative consequences of its existence (adverse selection, moral risks, etc.);

- expanding the range of financial services to increase market diversification and create additional market segments that will provide opportunities for the existence of «niche» banks;

- improving the monitoring of unscrupulous actions of participants in the banking system and enhancing responsibility for them.

Conclusions. In the research developed an approach to assessing the level of concentration in the banking system as an indicator of the occurrence of a crisis. It consists in the multi-stage analysis using special statistical tests (parametric and non-parametric), a set of special indicators for assessing market concentration (the Concentration Ratio CR4; the Herfindahl-Hirschman Index; the Rosenbluth Index; the Comprehensive Industrial Concentration Index; the Entropy Measure; the Gini Coefficient) and regression analysis with dummy variables.

The approbation of the developed approach to the data of the banking system of Ukraine revealed the degradation of this market from the point of view of its concentration. The use of special statistical tests (both parametric and non-parametric) revealed the heterogeneity of the banking system. These findings are confirmed by the results of calculations of market concentration ratios.

Based on this, the transition of the banking system of Ukraine from a relatively highly competitive environment to a market with a high level of concentration is identified. By its indicators, the banking system of Ukraine is approaching oligopoly.

The obtained results suggest that in order to overcome the first threats of a crisis, the National Bank of Ukraine, as the main regulator of the banking system, should develop and apply measures aimed at decreasing the concentration of assets and, later, when the situation stabilizes, create favourable conditions for banks to increase their portfolios.

Such processes form the internal instability of the system.

Thus, the results of the study are extremely important from the point of view of the organization of preventive crisis management, the main purpose of which will not be to combat the effects of the crisis but to eliminate its basic causes even before the fact of the crisis itself.

Further studies will be devoted to the formation of a composite indicator of the financial stability of the banking system and the definition of its inte with the level of concentration.

Author Contributions: conceptualization, T. V.; methodology, T. V. and A. S.; validation, T. V.; formal analysis, A. S.; investigation, A. S.; resources, A. S.; data curation, A. S.; writing-original draft preparation, A. S.; writing-review and editing, T. V.; visualization, A. S.; supervision, T. V.; project administration, T. V. 
T. Vasiljeva, A. Stadnyk. Innovative Approaches to Evaluation of Concentration of the Banking System as a Basis of Improving the State Crisis Management

\section{References}

Alegria, C., and Schaeck, K. (2006). On Measuring Concentration in Banking Systems. SSRN Electronic Journal. doi:10.2139/ssrn.949056.

Amidu, M., and Wolfe, S. (2013). Does bank competition and diversification lead to greater stability? Evidence from emerging markets. Review of Development Finance, 3(3), 152-166. doi:10.1016/j.rdf.2013.08.002.

Barra, C., and Zotti, R. (2017). Bank Performance, Financial Stability and Market Competition: do Cooperative and NonCooperative Banks Behave Differently. CELPE Discussion Papers, 143.

Beck, T., Demirguç-Kunt, A., and Levine, R. (2006). Bank concentration, competition, and crises: First results. Journal of Banking and Finance, 30(5), 1581-1603. doi:10.1016/j.jbankfin.2005.05.010.

Bekmurodova Adhamovna, G. (2014). Banking Competition and Stability: Comprehensive Literature Review. International Journal of Management Science and Business Administration, 2(6), 26-33. doi:10.18775/ijmsba.1849-5664-5419.2014.26.1002.

Ben Ali, M. S., Intissar, T., and Zeitun, R. (2018). Banking Concentration and Financial Stability. New Evidence from Developed and Developing Countries. Eastern Economic Journal, 44(1), 117-134. doi:10.1057/eej.2016.8.

Bikker, J. A., and Haaf, K. (2002). Competition, concentration and their relationship: An empirical analysis of the banking industry. Journal of Banking and Finance, 26(11), 2191-2214. doi:10.1016/s0378-4266(02)00205-4.

Bikker, J., and Spierdijk, L. (2017). Handbook of Competition in Banking and Finance. doi:10.4337/9781785363306.

Bouvatier, V., Lepetit, L., Rehault, P. N., and Strobel, F. (2018). Bank insolvency risk and Z-score measures: caveats and best practice.

Boyd, J. H., De Nicolo, G., and Jalal, A. M. (2009). Bank Competition, Risk and Asset Allocations. IMF Working Papers, 09(143), 1. doi:10.5089/9781451872903.001.

Calice, P., and Leonida, L. (2018). Concentration in the Banking Sector and Financial Stability: New Evidence. Policy Research Working Papers. doi:10.1596/1813-9450-8615

Cetorelli, N. (2004). Real Effects of Bank Competition. SSRN Electronic Journal. doi:10.2139/ssrn.505982.

Claessens, S. (2009). Competition in the Financial Sector: Overview of Competition Policies. IMF Working Papers, 09(45), 1. doi:10.5089/9781451871937.001.

Corder, G. W., and Foreman, D. I. (2011). Nonparametric Statistics for Non-Statisticians: A Step-by-Step Approach. Hoboken, $\mathrm{NJ}$ : John Wiley \& Sons.

Davis, K. (2007). Banking concentration, financial stability and public policy. The Structure and Resilience of the Financial System, ed. by C. Kent and J. Lawson.

Deltuvaite, V. (2010). The Concentration-Stability Relationship in The Banking System: an Empirical Research. Economics \& Management.

Diallo, B. (2015). Bank competition and crises revisited: New results. Economics Letters, 129, 81-86. doi:10.1016/j.econlet.2015.02.015.

Djalilov, K., Lyeonov, S., and Buriak, A. (2015). Comparative studies of risk, concentration and efficiency in transition economies. Risk Governance and Control: Financial Markets \& Institutions, 5(4). doi:10.22495/rgcv5i4c1art7.

Doll, M. (2010). Bank concentration, competition and financial stability. Prieiga per Interneta: < arno. uvt. nl/show. cgi.

Florian, L. (2014). Measuring competition in banking: A critical review of methods (No. 201412).

Heggestad, A. A., and Rhoades, S. A. (1978). Multi-Market Interdependence and Local Market Competition in Banking. The Review of Economics and Statistics, 60(4), 523. doi:10.2307/1924244.

Kasman, S., and Kasman, A. (2015). Bank competition, concentration and financial stability in the Turkish banking industry. Economic Systems, 39(3), 502-517. doi:10.1016/j.ecosys.2014.12.003.

Moore, D. S., McCabe, G. P., and Craig, B. A. (2014). Introduction to the Practice of Statistics. Macmillan Higher Education.

Mynhardt, R. H., Plastun, A., and Makarenko, I. (2017). Competitiveness of the Ukrainian Audit Market. Risk Governance and Control: Financial Markets \& Institutions, 7(2). doi:10.22495/rgcv7i2c1p6.

Naldi, M., and Flamini, M. (2014). The CR4 Index and the Interval Estimation of the Herfindahl-Hirschman Index: an Empirical Comparison. SSRN Electronic Journal. doi:10.2139/ssrn.2448656.

Plastun, A., Makarenko, I., and Balatskyi, I. (2018). Competitiveness in the Ukrainian stock market and local crisis of 2013-

2015. Investment Management and Financial Innovations, 15(2), 29-39. doi:10.21511/imfi.15(2).2018.03.

Repkova, I., and Stavarek, D. (2014). Concentration and competition in the banking sector of Turkey. Amfiteatru Economic, 16(36), 625.

Rhoades, S. A. (1995). Market share inequality, the $\mathrm{HHI}$, and other measures of the firm-composition of a market. Review of industrial organization, 10(6), 657-674.

Schaeck, K., and Cihak, M. (2013). Competition, Efficiency, and Stability in Banking. Financial Management, 43(1), 215-241. doi:10.1111/fima.12010.

Schaeck, K., Cihak, M., and Wolfe, S. (2009). Are Competitive Banking Systems More Stable? Journal of Money, Credit and Banking, 41(4), 711-734. doi:10.1111/j.1538-4616.2009.00228.x.

Shijaku, G. (2017). Does Concentration Matter for Bank Stability? Evidence from the Albanian Banking Sector. Journal of Central Banking Theory and Practice, 6(3), 67-94. doi:10.1515/jcbtp-2017-0021. 
T. Vasiljeva, A. Stadnyk. Innovative Approaches to Evaluation of Concentration of the Banking System as a Basis of Improving the State Crisis Management

The National Bank of Ukraine (2004-2018). Information about financial statements of banks in Ukraine 2004 - 2018. [Retrieved 2019-01-03] Available at: http://www.bank.gov.ua/control/uk/publish/category?cat id=64097 (in Ukr).

The National Bank of Ukraine (2004-2018). Key indicators of banks in Ukraine 2004 - 2018. [Retrieved 2019-01-03] Available at: https://bank.gov.ua/control/uk/publish/article?art_id=34661442\&cat_id=34798593 (in Ukr).

Titko, J., Kozlovskis, K., and Kaliyeva, G. (2015). Competition-stability relationship in the banking sector. Systemics, Cybernetics and Informatics, 13(2), 25-31.

Тетяна Васильєва, D.Sc., профресор, Університет бізнесу, мистецтв та технологій (Латвія);

Антон Стадник, директор, Перший Український Міжнародний Банк «ПУМБ»; Сумський державний університет (Україна).

Інноваційні підходи до оцінки концентрації банківської системи як основа для вдосконалення державного антикризового управління

З сукупності ендогенних факторів, що впливають на виникнення банківських криз, найменш вивченим та найбільш неоднозначним, на наш погляд, є ефеект концентрації. Ми вважаємо, що в сучасних умовах розвитку як світової економіки, так і економіки України, оцінка рівня концентрації має бути одним з ключових елементів державного антикризового управління банківською системою, оскільки зростання ринкової концентрації може виступати як сигнал щодо майбутньої деградації ринку та можливої кризи на ньому. Зважаючи на це, авторами запропоновано інноваційні підходи до оцінки рівня концентрації в банківській системі, що полягають у комплексному та багатоетапному аналізі ринку банківських послуг з використанням спеиіальних статистичних тестів (параметричний тест ANOVA та непараметричний тест Крускала-Волліса), набору спеціальних показників оцінки концентрації ринку (коефіцієнт концентрації CR4, індекс Херфріндаля-Гіршмана, індекс Розенблюта, загальний індекс галузевої концентрації, індекс ентропії, коефіцієнт Джині) та регресійного аналізу з фіктивними змінними. Емпіричний аналіз базується на даних банківської системи України з 2004 по 2017 рік для вибірки банків, сформованої шляхом розподілу масиву даних, що аналізуються, на дві групи (основні учасники та група «інші банки») на базі використання порогового значення та приведення даних групи «інші банки» з використанням методу усереднення до стану, що дозволить визначити типов характеристики учасників ринку цієї групи. Дослідження дозволяє отримати аналітичний результат, який підтверджує що в банківській системі України спостерігається зростання концентрації. Наслідком иього є поступова деградація банківської системи, оскільки монополізація призводить до викривлення функкиіонвання ринкових механізмів. Для подолання перших загроз кризи Наиіональний банк України, як головний регулятор банківської системи, має розробити та застосувати заходи, спрямовані на зниження концентрації активів та створити сприятливі умови для нарощування банками портфелів активів.

Ключові слова: конкуренція банку, концентрація банку, банківські кризи, управління.

Manuscript received: 27.11.2018

(C) The author(s) 2019. This article is published with open access at Sumy State University. 